\title{
NUMERICAL ANALYSIS OF COLLISION OF THE MULTIMATERIAL BIRD MODEL WITH HELICOPTER WINDSHIELD
}

\author{
ANALIZA NUMERYCZNA ZDERZENIA \\ WIELOMATERIALOWEGO MODELU PTAKA \\ Z OSZKLENIEM KABINY ŚMIGLOWCA
}

\author{
Janusz Ćwiklak \\ Polish Air Force Academy \\ Wyższa Szkoła Oficerska Sił Powietrznych. Wydział Lotnictwa
}

\begin{abstract}
The aim of this article is to present findings of simulation research of a stork impact with a helicopter windshield. Besides we developed a numerical model of the stork, based on biometrical data, taking into account various properties of its head, neck, torso and wings. It appears that the research findings which take into consideration the bird's shape differ from those using a simplified bird model in the shape of a cylinder or a sphere. In order to conduct an analysis of a bird impact onto an aircraft windshield, we used the LS_DYNA software package. In the classic variant with the $3.6 \mathrm{~kg}$ bird model, cylinder-shaped with spherical endings, the windshield became damaged at the velocity of $200 \mathrm{~km} / \mathrm{h}$ for a standard windshield $(3.81 \mathrm{~mm})$. For the same velocity, we conducted simulation which used the multimaterial model. It appeared that the windshield did not become damaged. Therefore, the shape of the dummy bird also affects the velocity at which the damage occurs. Too wide simplification of the dummy bird shape may lead to lowered values of the velocity.
\end{abstract}

Keywords: bird strikes, multilateral model, numerical simulation

Streszczenie: $W$ artykule zaprezentowano wyniki badań symulacji zderzenia bociana $z$ oszkleniem helikoptera. Opracowano numeryczny model bociana w oparciu o dane biometryczne, uwzględniające różne właściwości fizyczne głowy, szyi, korpusu i skrzydet. Okazuje się, że wyniki badań uwzględniających ksztalt ptaka różnia się od tych, $w$ których stosuje sie uproszczony model ptaka w postaci walca, lub kuli. W celu dokonania analizy zderzenia ptaka z szyba statku powietrznego wykorzystano pakiet oprogramowania LS-DYNA. W klasycznym wariancie z 3,6 kg modelem ptaka o ksztatcie walcowym ze sferycznymi zakończeniami zniszczenie szyby nastapito przy prędkości $200 \mathrm{~km} / \mathrm{h}$ dla standardowej szyby $(3,81 \mathrm{~mm})$. Dla tej samej prędkości przeprowadzono symulacje z wykorzystaniem modelu wielomateriałowego. Okazuje sie, że zniszczenie szyby nie nastapiło. $W$ zwiazku z tym, ksztalt zastępczego ptaka wptywa również na prędkość, przy jakiej następuje pękanie szyby. Zbyt daleko posunięte uproszczenie ksztaltu zastępczego ptaka może, zatem prowadzić do zaniżonych wartości prędkości.

Stowa kluczowe: kolizje statków powietrznych z ptakami, wielomateriatowy model ptaka, symulacje numeryczne 
Numerical analysis of collision of the multimaterial bird model with helicopter... Analiza numeryczna zderzenia wielomateriałowego modelu ptaka...

\section{NUMERICAL ANALYSIS OF COLLISION \\ OF THE MULTIMATERIAL BIRD MODEL WITH HELICOPTER WINDSHIELD}

\section{Introduction}

As proved in the conducted analyses, one of the factors which significantly exerts a negative influence on flight safety, is a potential possibility of a collision of an aircraft with birds, in particular at an airfield or in its vicinity $[12,16]$. Various parts of an aircraft are subjected to damage. It appears that damage to the engine as well as penetration of the windshield are extremely dangerous. The consequence of a bird sucked into the engine can be engine shutting down $[6,8]$, whereas penetrating the canopy can cause a serious injury to the pilot, making him unable to continue piloting an aircraft. It should be remembered that apart from the compulsory experimental strength tests, conducted in laboratory conditions in order to meet certification requirements, there exist various theoretical methods which are realized on the basis of proper mathematical modelling of the bird strikes $[5,10]$. Therefore, due to lack of certification requirements for the category of normal, utility, acrobatic aeroplanes and small helicopters and a high degree of damage, especially to the cockpit canopy, it seems justified to conduct simulation of the strike impact by means of proper software. In order to perform the modelling in question, it is necessary to select a proper bird model and a suitable simulation method, including appropriate software [4, 7, 9]. On the basis of the available literature devoted to the subject, there are several methods of modelling a bird shape. Investigations exploit various geometrical figures in order to model the bird shape, the most common one being a cylinder, an ellipsoid and a cylinder with hemispherical endings [4, 10, 15]. Few authors present research findings, which employ an approximate shape of a certain bird species on the basis of biometrical data [17]. Therefore, this article attempts to analyse a simulation of a storkstrike event onto a cockpit windshield of selected aircraft.

\section{The research methodology}

In order to conduct an analysis of a bird impact onto an aircraft windshield, we used the LS_DYNA software package [11, 19]. This is a computational code designed to analyse the fast changing phenomena by means of the finite-element method, developed by the American company Livermore Software Technology Corporation (LSTC), based in Livermore in California. The system exploits quick explicit formulation [2].

In the conducted analyses we used the SPH technique (Smoothed Particle Hydrodynamics), whose foundation is formed by particle systems [20, 22]. The SPH technique was exploited in computational FEM codes in order to avoid limitations connected with entangled finite elements network when solving problems of severe deformations $[18,19]$. 
The fundamental difference between the classic Langrangian approach and the SPH one is lack of any network [21]. The particles themselves create an object and the equations are solved for them.

For the accuracy of the SPH technique, it is important that the particle distribution should be as regular as possible, and should not have too large differences in distances among them. Within the conducted analyses, the impact loaded object was a helicopter windshield. We selected the windshield of Agusta A-109, manufactured by the concern of Agusta Westland ${ }^{22}$. The main criterion adopted at its selection was availability of the geometrical model CAD, downloaded from GrabCAD free cross-platform source [12] as well as the accessibility of the strength parameters of the material which the windshield was produced from.

\section{Windshield model}

The Agusta A-109 windshield is manufactured from acrylic glass [13]. The material available under various trademarks such as Plexiglas ${ }^{\mathrm{TM}}$, Perspex ${ }^{\mathrm{TM}}$, is mostly composed of polymethyl methacrylate - PMMA. The material parameters of this type of glass, mentioned in paper [5], have been listed in Table 1. We used the elastic-perfectly-plastic model (*MAT_PLASTIC_KINEMATIC) [1], with the modulus of reinforcement equalling 0 . The selected material model took into account destruction, therefore the elements of the windshield model in which failure strain was exceeded $(F S=0.067$, Table 1), underwent erosion, i.e. they were removed from the model during the simulation.

Table 1. Material data used in windshield model [5]

\begin{tabular}{|c|c|c|c|c|}
\hline \multicolumn{5}{|c|}{$*$ MAT_PLASTIC_KINEMTIC } \\
\hline Density & $\begin{array}{c}\text { Young's } \\
\text { modulus }\end{array}$ & Poisson's ratio & Yield stress & Failure strain \\
\hline RO $\left[\mathrm{kg} / \mathrm{m}^{3}\right]$ & $\mathrm{E}[\mathrm{Pa}]$ & PR $[-]$ & SIGY $[\mathrm{Pa}]$ & FS $[-]$ \\
\hline 1190 & $3,13 \cdot 10^{9}$ & 0,426 & $6,8 \cdot 10^{7}$ & 0,067 \\
\hline
\end{tabular}

\section{Bird model}

In order to build the bird model, we accepted a shape close to the real-life one, where we assumed the following data:

- $\operatorname{mass}=3.6 \mathrm{~kg}$;

- the torso constitutes $70 \%$ of the body mass;

- the material densities for the head, neck and torso were accepted on the basis of paper [3], where the authors described a Canadian goose; however, disregarding the bird's beak, the densities of the mentioned components should not vary too much; the densities equalled $900 \mathrm{~kg} / \mathrm{m}^{3}$ - head; $1,500 \mathrm{~kg} / \mathrm{m}^{3}-$ neck; 1,150 $\mathrm{kg} / \mathrm{m}^{3}$ - torso, respectively;

- the density of the wings was adjusted in such a way that the total width of the bird model does not exceed the windshield width since it would require considerable modifications of the present model. Besides, the wing density was determined by the total mass of the bird model and ultimately equalled $590 \mathrm{~kg} / \mathrm{m}^{3}$. 
Numerical analysis of collision of the multimaterial bird model with helicopter... Analiza numeryczna zderzenia wielomateriałowego modelu ptaka...

While generating the bird model, we assumed the following simplifications:

- we disregarded the beak, feet and the tail of the bird;

- the shapes of the torso and the head were assumed to be cylindrical with semispherical endings;

- the neck shape was assumed to be cylindrical;

- we assumed a rectangular wing shape, with rounded wing edges.

The bird model used a "zero" material model (*MAT_NULL), where we declared the Grüneisen equation of state (*EOS_GRUNEISEN). The equation defines the pressure in shock-compressed material, as [14]:

$$
p=\rho_{0} C^{2} \mu\left\{\frac{\left[1+\left(1-\frac{\gamma_{0}}{2}\right) \mu-\frac{a}{2} \mu^{2}\right]}{\left[1-\left(S_{1}-1\right) \mu-S_{2} \frac{\mu^{2}}{\mu+1}-S_{3} \frac{\mu^{3}}{(\mu+1)^{2}}\right]^{2}}\right\}+\left(\gamma_{0}+a \mu\right) E,
$$

whereas for the expanded material, as:

$$
p=\rho_{0} C^{2} \mu+\left(\gamma_{0}+a \mu\right) E,
$$

where:

$C-$ bulk speed of sound; $\quad \gamma_{0}-$ Grüneisen gamma; $\quad S_{1}-$ linear coefficient;

$S_{2}-$ quadratic coefficient; $\quad S_{3}-$ cubic coefficient; $\quad \rho-$ actual density;

$a$ - first order volume correction to $\gamma_{0} ; E-$ internal energy per unit of mass.

$\mu-$ volume parameter, expressed as $\mu=\left(\rho / \rho_{0}\right)-1 ; \quad \rho_{0}-$ initial density;

The material data of a dummy bird have been listed in table 2 .

Table 2 Material data used in bird model [5]

\begin{tabular}{|c|c|c|c|}
\hline \multicolumn{2}{|c|}{$*$ MAT_NULL } & \multicolumn{2}{c|}{ *EOS_GRUNEISEN } \\
\hline Cut-off pressure & Viscosity coefficient & Bulk speed of sound & Linear coefficient \\
\hline PC $[\mathrm{Pa}]$ & $\mathrm{MU}[\mathrm{Pa} \cdot \mathrm{s}]$ & $\mathrm{C}[\mathrm{m} / \mathrm{s}]$ & $\mathrm{S} 1[-]$ \\
\hline$-10^{6}$ & 0,001 & 1647 & 2,48 \\
\hline
\end{tabular}

Taking into consideration the above data as well as the used simplifications, we obtained a bird model, $3.604 \mathrm{~kg}$ in mass, composed of 29,972 SPH particles. This bird model depicts Fig. 1a. The simulation results were compared with the results of the dummy bird model, cylinder-shaped, with spherical endings shown in Fig. 1b, also $3.6 \mathrm{~kg}$ in mass and the equal number of SPH particles. 
(a)

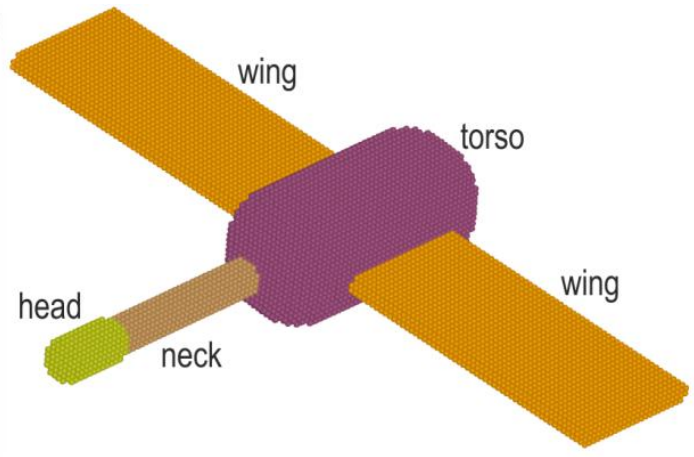

(b)

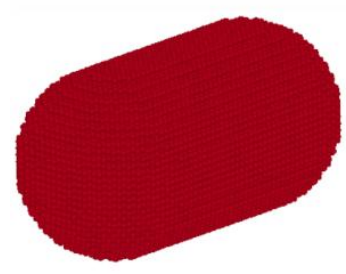

Fig. 1. Multimaterial bird model used in FEM analyses (a) and cylinder-shaped model, with spherical endings $(b)$.

\section{Results and discussions}

The first analyses were conducted for the helicopter cruising speed, i.e. $285 \mathrm{~km} / \mathrm{h}$. The findings in the form of time curves of pressure and the windshield deflection have been presented in Fig. 2, referring them to analogous curves, obtained for the bird model, cylinder-shaped with spherical endings. While analysing the obtained findings, it is possible to draw a conclusion that the adopted bird model significantly affects the windshield behaviour. The curves of pressure for the multimaterial model differ from those obtained from the single material model. There are two value peaks - the first one which corresponds to the head strike, or to be more accurate - the neck of very high density, and the other one, connected with the torso strike. Windshield deflections reach approximate extreme values, nevertheless it is possible to observe slower increase in deflection, connected with the head contact, next the neck and finally the bird's torso.
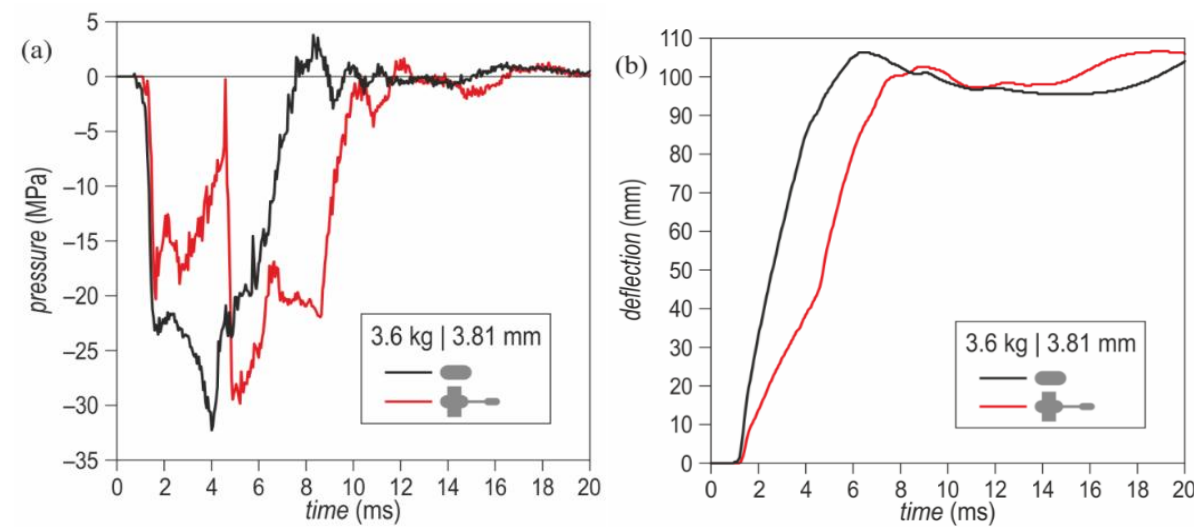

Fig. 2. Time curves of pressure (a) and windshield deflection (b) at the impact strike velocity of $285 \mathrm{~km} / \mathrm{h}$

The deformations in selected moments of time have been compared in Fig. 3. 
Numerical analysis of collision of the multimaterial bird model with helicopter... Analiza numeryczna zderzenia wielomateriałowego modelu ptaka...

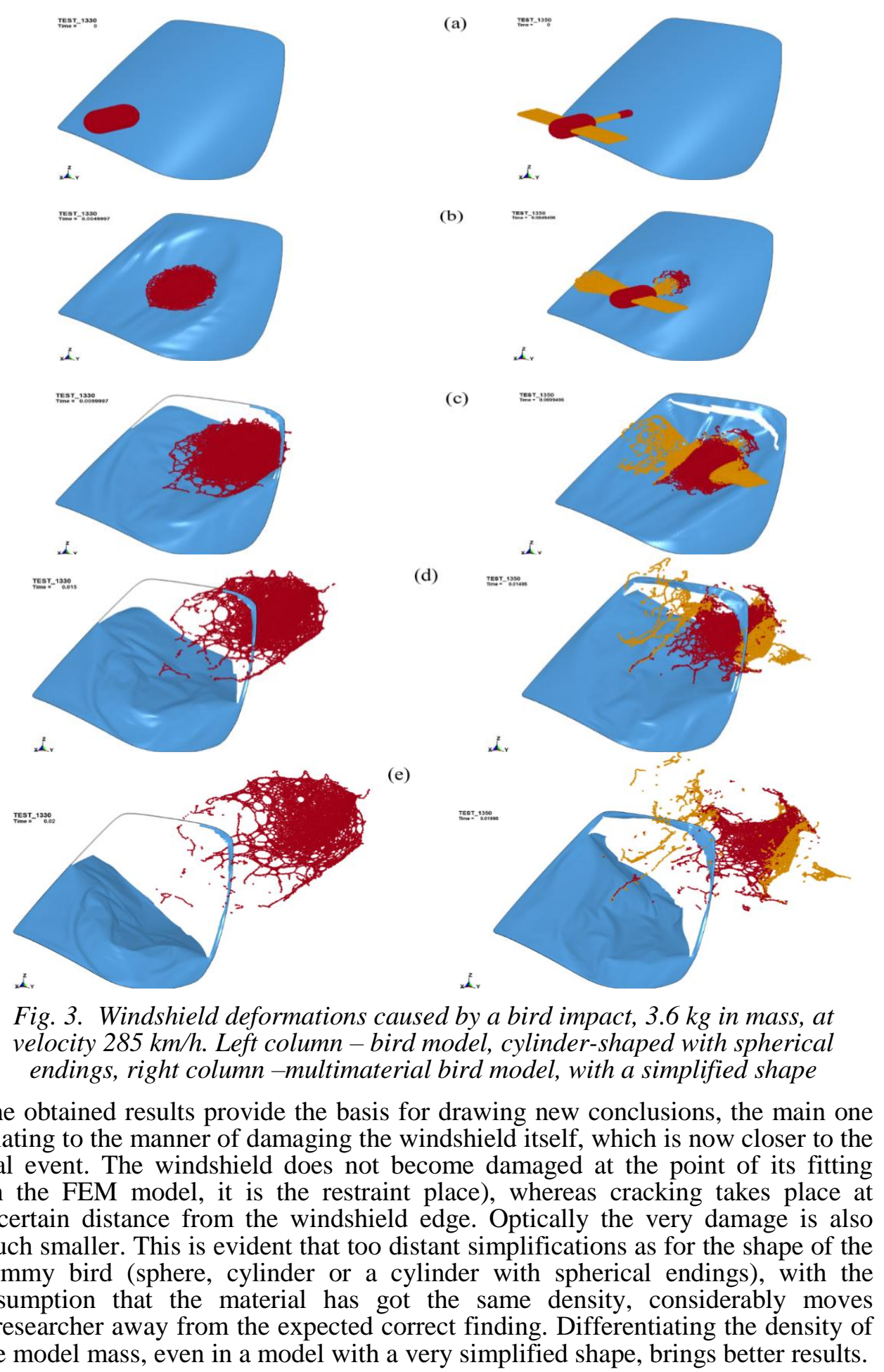


Janusz Ćwiklak

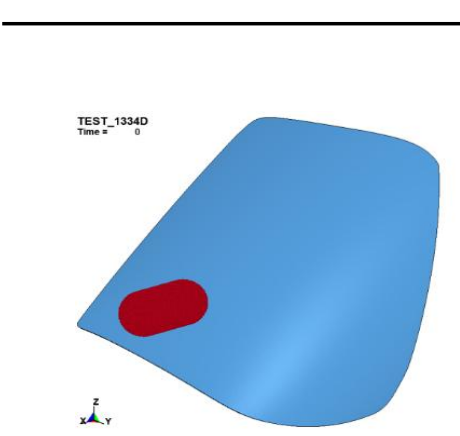

(a)
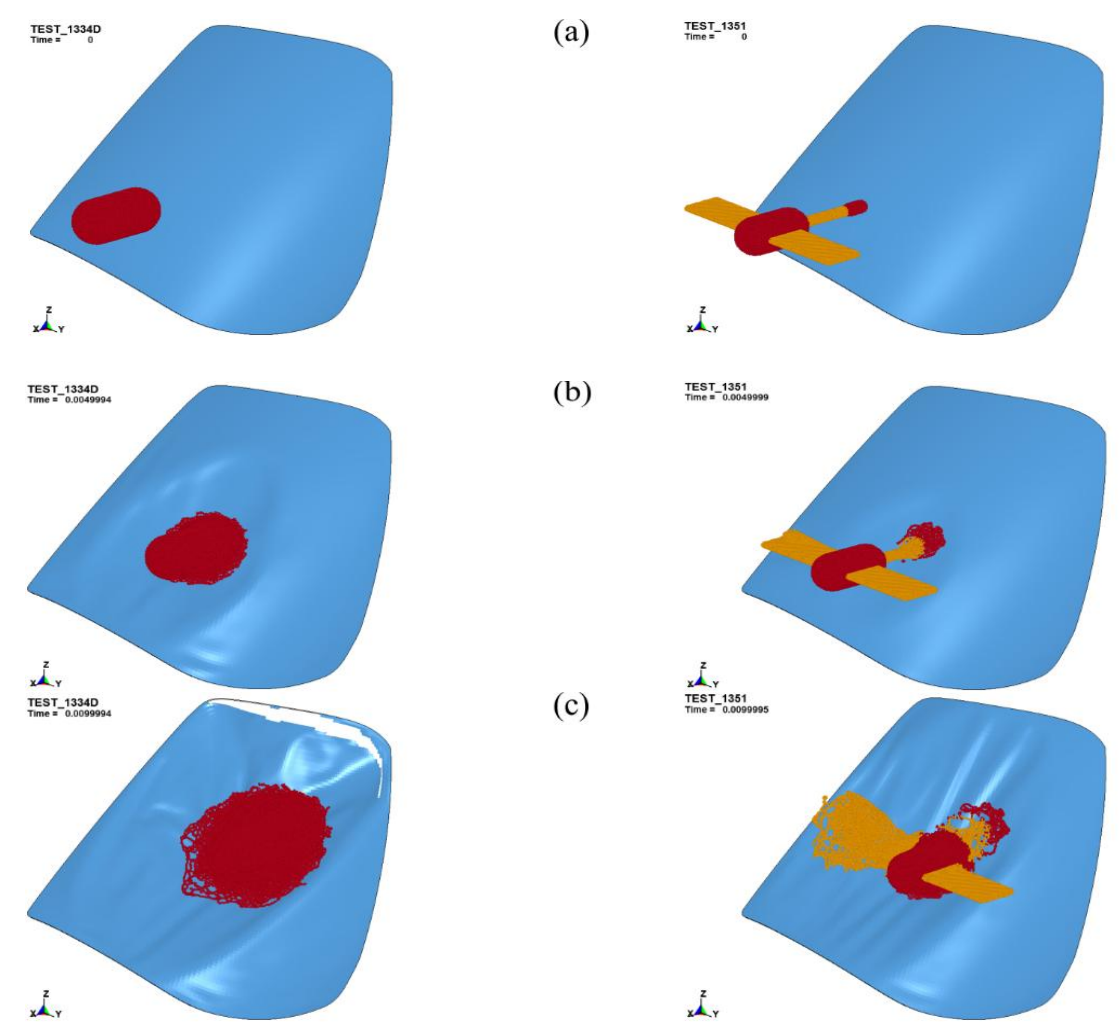

(b)
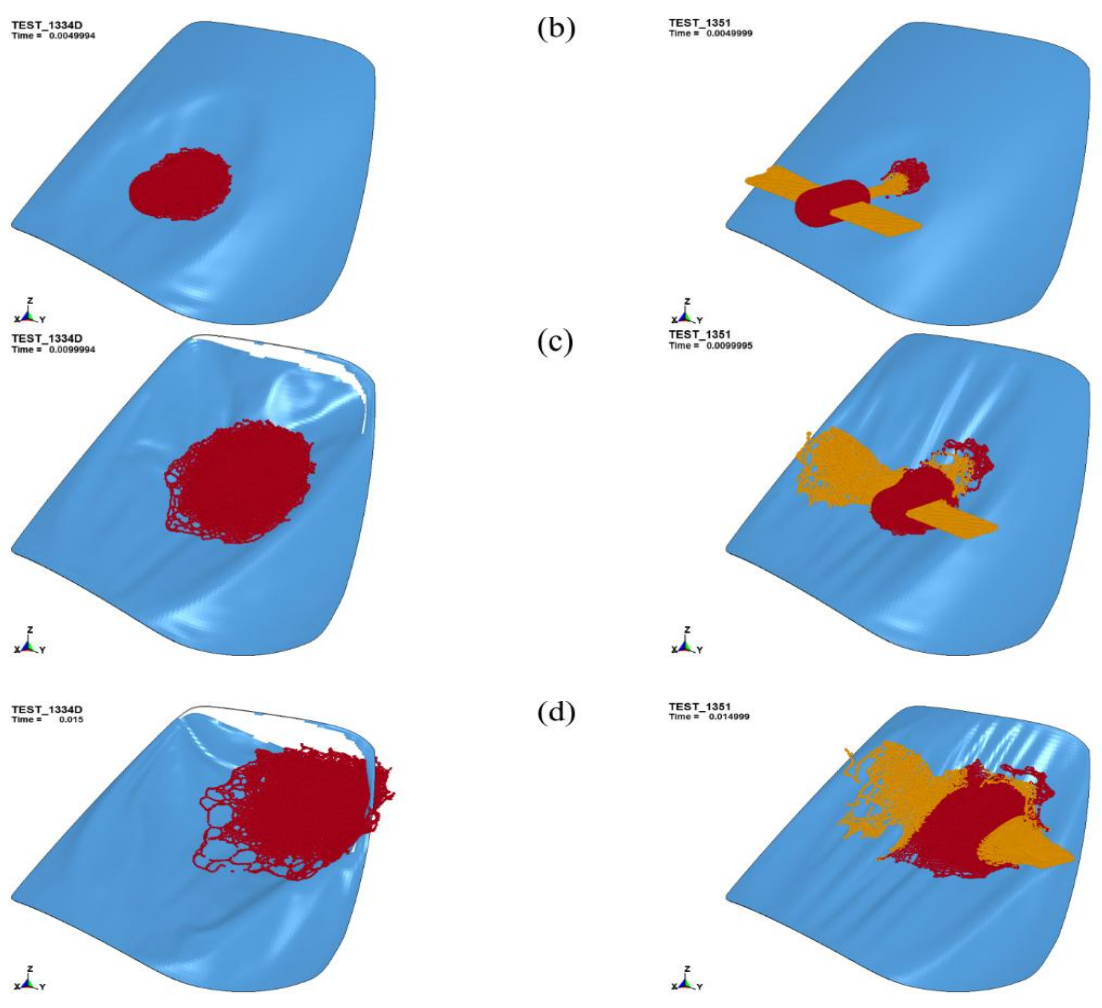

(d)
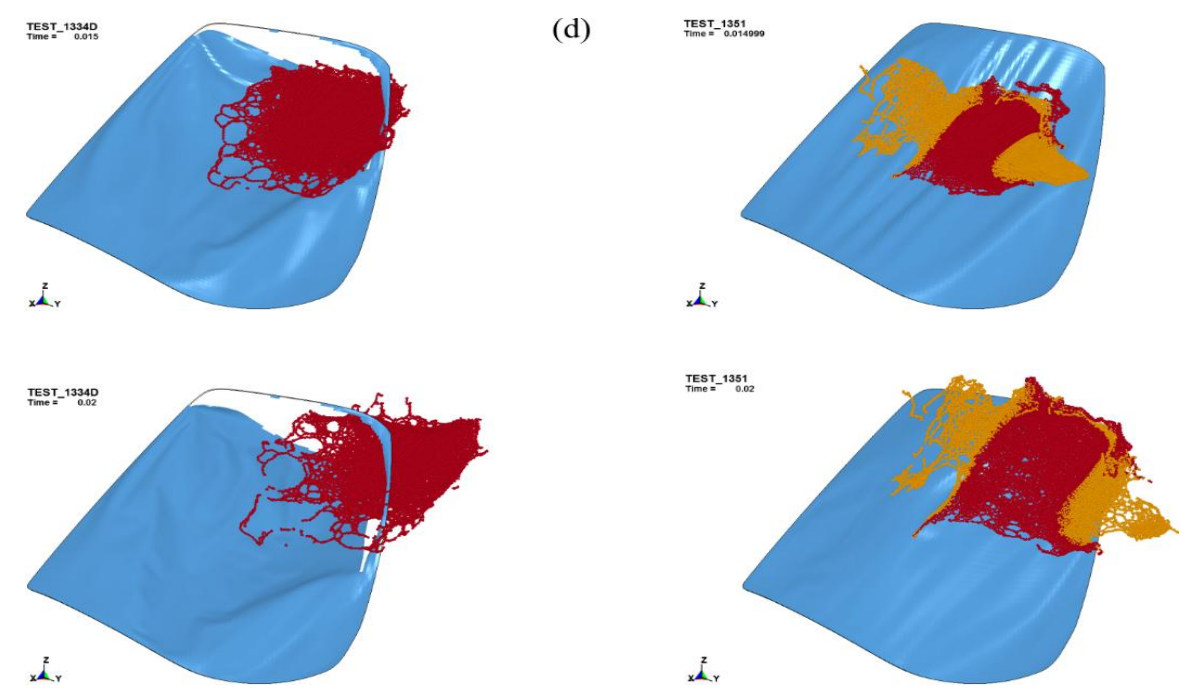

Fig. 4. Windshield deformations caused by a bird impact, $3.6 \mathrm{~kg}$ in mass at velocity $220 \mathrm{~km} / \mathrm{h}$. Left column - bird model, cylinder-shaped with spherical endings, right column-multimaterial bird model, with a simplified shape. 
Numerical analysis of collision of the multimaterial bird model with helicopter... Analiza numeryczna zderzenia wielomateriałowego modelu ptaka...

An interesting comparative analysis might be checking whether applying the multimaterial bird model affects velocity at which the windshield becomes shattered. In the classic variant with the $3.6 \mathrm{~kg}$ bird model, cylinder-shaped with spherical endings, the windshield became damaged at the velocity of $200 \mathrm{~km} / \mathrm{h}$ for a standard windshield $(3.81 \mathrm{~mm})$. For the same velocity, we conducted simulation which used the multimaterial model. It appeared that the windshield did not become damaged (Fig. 4). Therefore, the shape of the dummy bird also affects the velocity at which the damage occurs. Too wide simplification of the dummy bird shape may lead to lowered values of the velocity.
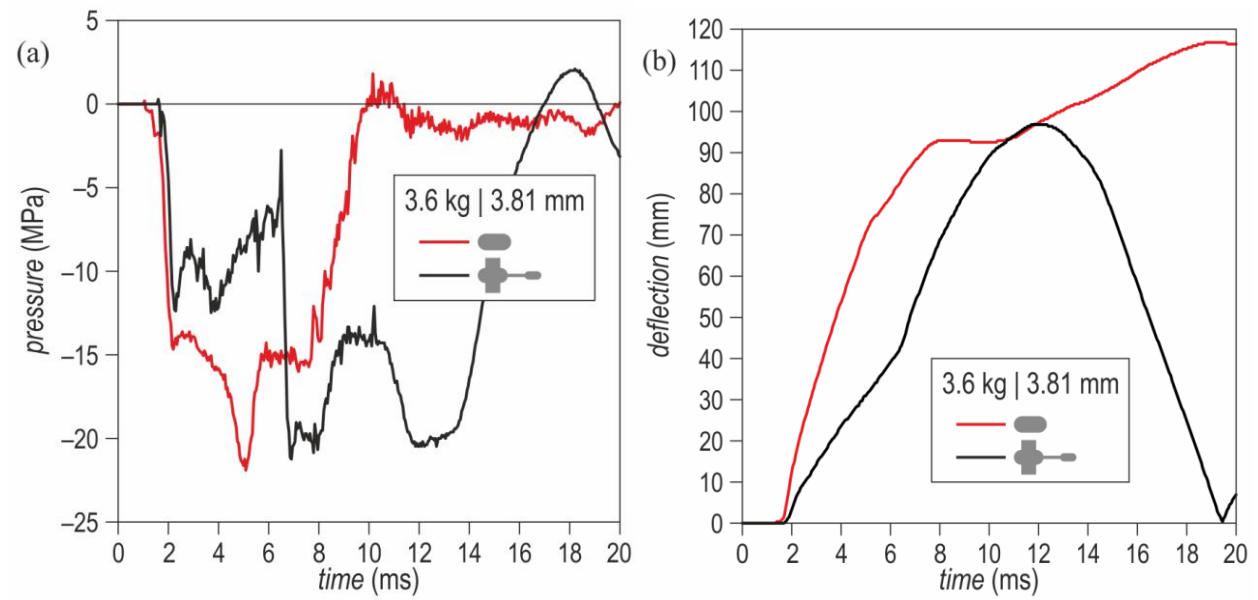

Fig. 5. Time curves of pressure (a) and windshield deflection (b) at impact velocity of $200 \mathrm{~km} / \mathrm{h}$. Bird mass $-3.6 \mathrm{~kg}$, windshield thickness $-3.81 \mathrm{~mm}$.

Time curves of the selected values, at the velocity of $200 \mathrm{~km} / \mathrm{h}$, have been listed in Fig. 5. They refer to the bird model, cylinder-shaped with spherical endings, in case of which the windshield became damaged, at this velocity, and for the multimaterial model, where the windshield remains intact.

Table 3. Permitted velocities of dummy bird impact onto windshield, $3.6 \mathrm{~kg}$ in mass, when the windshield remains undamaged

\begin{tabular}{|l|c|c|}
\hline \multirow{2}{*}{ Bird model } & \multicolumn{2}{|c|}{ Windshield thickness } \\
\cline { 2 - 3 } & $3,81 \mathrm{~mm}$ & $5,00 \mathrm{~mm}$ \\
\hline single material, cylinder-shaped with spherical endings & $195 \mathrm{~km} / \mathrm{h}$ & $210 \mathrm{~km} / \mathrm{h}$ \\
\hline multimaterial with simplified shape & $235 \mathrm{~km} / \mathrm{h}$ & $275 \mathrm{~km} / \mathrm{h}$ \\
\hline
\end{tabular}

Table 3 lists the values of bird-strike velocities, when the windshield remained undamaged. We compared the single material and multimaterial model in case of a head-on impact onto the windshield of the helicopter in question. It can be observed that in case of a model whose shape is very close to a real bird, the obtained values are much higher, thus simplifying the shape to a cylinder does not bring reliable findings. 


\section{Conclusions}

The bird model which is used in the analyses of collisions with an aircraft windshield, must be made to a great degree of detail, if we expect the findings to be very close to the real-life ones, occurring in real-life conditions. Too big simplifications of the shape of the bird's model may only serve as preliminary, rough assessment of the windshield behaviour as a result of a bird strike. Depending upon the degree of complexity in the bird's model, we obtain significantly different forms of the windshield deformation as well as varied curves of the registered values.

The applied homogeneous material model, which also uses Grüneisen state of equation, accurately reflects the behaviour of the bird model during large deformations, in consequence of a bird impact onto a windshield. Nevertheless, it is advisable to exploit multimaterial models, of varied mass density of particular components.

More emphasis should be put on more accurate reflection of the windshield fitting. This paper assumes full fitting of the windshield on the perimeter, however it does not reflect the real manner of fitting. Summing up, the conducted numerical analyses shed light over certain aspects of a bird strike onto a helicopter windshield. Although we considered a reverse phenomenon, when the bird hits an immobile windshield, such an approach is often described in literature. The obtained findings come very close to those presented in the papers dealing with this issue, including $[3,5]$. The suggested multimaterial dummy bird model, with a simplified shape, seems to be sufficient for this type of analyses. It serves as a compromise between the models of basic shapes (sphere, cylinder) and models faithfully reflecting the bird, which are difficult to generate and verify.

\section{References}

[1] Marulo F., Guida M., Design criteria for birdstrike damage on windshield, Advances in Aircraft and Spacecraft Science, Vol. 1, No. 2, 2014, pp. 233-251.

[2] Bird strike simulation on a wing slat using Abaqus/Explicit, Abaqus Technology Brief, TB-10-BIRD-1, 2010.

[3] McCallum S. C., Constantinou C., The influence of bird-shape in bird-strike analysis, 5th European LS-DYNA Users Conference, Paper No. 2c-77, Birmingham, United Kingdom 2005.

[4] Heimbs S., Computational methods for bird strike simulations: A review, Computers and Structures, Vol. 89, 2011, pp. 2093-2112.

[5] Wang F. S., Yue Z.F., Yan W. Z., Factors study influencing on numerical simulation of aircraft windshield against bird strike, Shock and Vibration, Vol. 18, 2011, pp. 407-424.

[6] Boguszewicz P., Sala S., Bird Strike, czyli zderzenie z ptakiem, Prace Instytutu Lotnictwa, Vol. 213, s. 101-111, 2011. 
Numerical analysis of collision of the multimaterial bird model with helicopter... Analiza numeryczna zderzenia wielomateriałowego modelu ptaka...

[7] Jun L., Yulong L., Xiaosheng G., Xiancheng Y., A numerical model for bird strike on sidewall structure of an aircraft nose, Chinese Journal of Aeronautics, Vol. 27, No. 3, 2014, pp. 542-549.

[8] Safety Recommendation, A-09-72 through -81, National Transportation Safety Board, Washington, D.C. United States, 2009.

[9] Lavoie M.-A., Gakwaya A., Nejad Ensan M., Zimcik D. G., Review of existing numerical methods and validation procedure available for bird strike modelling, ICCES, Vol. 2, No. 4, 2007, pp. 111-118.

[10] Nagaraj V, Velmurugan T., Numerical bird strike impact simulation of aircraft composite structure, IOSR Journal of Mechanical and Civil Engineering.

[11] http://www.dynaexamples.com/sph.

[12] https://grabcad.com/library/augusta-a-109-1.

[13] N109TK, EW/C2011/07/10, AAIB Bulletin, 3/2012.

[14] LS-DYNA ${ }^{\circledR}$ Keyword User's Manual, Vol. I, Livermore Software Technology Corporation, USA 2007.

[15] Allcock A. W. R., Collin D. M., The development of a dummy bird for use in bird strike research, Aeronautical Research Council, C.P. No. 1071, Ministry of Technology, United Kingdom 1969.

[16] http://www.agustawestland.com/product/helicopters/aw109-power-2.

[17] http://www.dynasupport.com/tutorial/ls-dyna-users-guide/time-integration.

[18] Konderla P., Metoda Elementów Skończonych, teoria i zastosowania, kurs na studiach doktoranckich Politechniki Wrocławskiej, Wrocław 2007.

[19] LS-DYNA ${ }^{\circledR}$ Theory Manual, Livermore Software Technology Corporation, USA 2006 .

[20] Wróblewski P., Algorytmy symulacji płynów rzeczywistych bazujące na modelach DPD oraz SPH dla komputerów z pamięcią współdzieloną oraz rozproszoną, rozprawa doktorska, Akademia Górniczo-Hutnicza w Krakowie, Kraków 2009.

[21] Wróblewski P., Boryczko K., Implementacja równoległa, zastosowania i wyniki metody SPH w przypadku symulacji płynów nieściśliwych, Automatyka, t. 12, z. 2, 2008, s. 389-406.

[22] https://pl.wikipedia.org/wiki/SPH. 


\section{ANALIZA NUMERYCZNA ZDERZENIA WIELOMATERIALOWEGO MODELU PTAKA $Z$ OSZKLENIEM KABINY ŚMIGLOWCA}

\section{Wstęp}

Jak wskazują wnioski z przeprowadzonych analiz, jednym z czynników, który znacząco wpływa negatywnie na bezpieczeństwo lotów, jest potencjalna możliwość kolizji statków powietrznych z ptakami, szczególnie na lotnisku i w jego pobliżu $[12,16]$. Uszkodzeniu ulegają różne elementy statku powietrznego. Okazuje się, że uszkodzenie silnika oraz przebicie oszklenia kabiny należą do zdarzeń bardzo niebezpiecznych. W następstwie wpadnięcia ptaka do silnika może nastąpić jego wyłączenie $[6,8]$, natomiast po przebiciu oszklenia kabiny, istnieje bezpośrednie zagrożenie poważnego zranienia pilota uniemożliwiającego dalsze pilotowanie statku powietrznego. Istotnym jest zauważyć, że oprócz obowiązkowych, eksperymentalnych prób wytrzymałościowych przeprowadzanych na stanowiskach laboratoryjnych $\mathrm{w}$ celu spełnienia wymagań certyfikacyjnych, istnieją różne metody teoretyczne realizowane w oparciu o odpowiednie modelowanie matematyczne zderzenia $[5,10]$. Aby przeprowadzić przedmiotowe modelowanie należy opracować odpowiedni model ptaka oraz zastosować odpowiednią metodę symulacji $[4,7,9]$. Jak wynika $\mathrm{z}$ analizy literatury przedmiotu badań istnieje kilka metod modelowania kształtu ptaka. W badaniach tych wykorzystuje się różne figury geometryczne do modelowania kształtu ptaka. Do najczęściej stosowanych należą: walec, elipsoida oraz walec ze sferycznymi zakończeniami $[4,10,15]$. Natomiast niewielu autorów prezentuje wyniki badań, w których przyjęto przybliżony kształt określonego gatunku ptaka na podstawie danych biometrycznych [17]. Dlatego w niniejszym artykule podjęto próbę analizy symulacji zderzenia modelu bociana z oszkleniem kabiny helikoptera.

\section{Metody badań}

W celu dokonania analizy zderzenia ptaka $\mathrm{z}$ szybą statku powietrznego wykorzystano pakiet oprogramowania LS-DYNA [11,19]. Jest to kod obliczeniowy do analizy zjawisk szybkozmiennych metodą elementów skończonych rozwijany przez amerykańską firmę Livermore Software Technology Corporation (LSTC) w Livermore w Kalifornii. System wykorzystuje szybkie sformułowanie jawne typu explicit [2].

W przeprowadzonych analizach wykorzystano technikę SPH (Smoothed Particle Hydrodynamics), której podstawą są systemy cząstek [20,22]. Technika SPH została wykorzystana w kodach komputerowych MES w celu uniknięcia ograniczeń związanych z plątaniem się siatki elementów skończonych podczas rozwiązywania zagadnień z silnymi deformacjami [18,19]. Zasadniczą równicą pomiędzy klasycznym podejściem lagrange'owskim oraz SPH jest brak siatki [21]. 
Numerical analysis of collision of the multimaterial bird model with helicopter... Analiza numeryczna zderzenia wielomateriałowego modelu ptaka...

Same cząsteczki tworzą obiekt i dla nich rozwiązuje się równania. Dla poprawności techniki SPH ważne jest, aby rozkład cząstek był jak najbardziej regularny i nie zawierał zbyt dużych różnic $\mathrm{w}$ odległościach między nimi. W ramach prowadzonych analiz, obiektem uderzanym była szyba przednia śmigłowca. Wybrano szybę śmigłowca Agusta A-109, produkowanego przez koncern Agusta Westland. Głównym kryterium, jakim kierowano się przy jego wyborze, była dostępność modelu geometrycznego CAD, który został pobrany $\mathrm{z}$ darmowej bazy GrabCAD [12], jak również dostępność parametrów wytrzymałościowych materiału, z którego wykonano szybę.

\section{Model szyby}

Szyba śmigłowca Agusta A-109 wykonana jest ze szkła akrylowego [13]. Materiał ten występuje pod różnymi nazwami handlowymi producentów, np.: Plexiglas ${ }^{\mathrm{TM}}$, Perspex ${ }^{\mathrm{TM}}$. Jego głównym składnikiem jest poli(metakrylan metylu) - PMMA. Parametry materiałowe tego typy szkła, które podano w pracy [5], zestawiono w tabeli 1. Zastosowano model sprężysto idealnie plastyczny (*MAT_PLASTIC_KINEMATIC) [1], przy czym moduł wzmocnienia był równy 0 . Zastosowany model materiałowy uwzględniał niszczenie, w związku z czym elementy modelu szyby, w których przekroczone zostały odkształcenia niszczące (FS $=0,067$, tabela 1$)$, ulegały erozji, tj. były usuwane $\mathrm{z}$ modelu $\mathrm{w}$ trakcie symulacji.

Tabela 1. Dane materiatowe wykorzystane w modelu szyby [5]

\begin{tabular}{|c|c|c|c|c|}
\hline \multicolumn{5}{|c|}{ *MAT_PLASTIC_KINEMTIC } \\
\hline gęstość & $\begin{array}{c}\text { moduł } \\
\text { Younga }\end{array}$ & stała Poissona & $\begin{array}{c}\text { granica } \\
\text { plastyczności }\end{array}$ & $\begin{array}{c}\text { odkształcenia } \\
\text { niszczące }\end{array}$ \\
\hline RO $\left[\mathrm{kg} / \mathrm{m}^{3}\right]$ & $\mathrm{E}[\mathrm{Pa}]$ & PR $[-]$ & SIGY $[\mathrm{Pa}]$ & FS $[-]$ \\
\hline 1190 & $3,13 \cdot 10^{9}$ & 0,426 & $6,8 \cdot 10^{7}$ & 0,067 \\
\hline
\end{tabular}

\section{Model ptaka}

Do budowy modelu bociana, przyjęto kształt zbliżony do rzeczywistego, dla którego założono następujące dane:

- masa $=3,6 \mathrm{~kg}$;

- $70 \%$ masy stanowi korpus ptaka;

- gęstości materiału dla głowy, szyi i tułowia przyjęto na podstawie pracy [3], w której autorzy rozpatrywali gęś, nie mniej jednak, pomijając dziób ptaka, gęstości wspomnianych komponentów nie powinny zbytnio odbiegać od siebie; gęstości te wynosiły odpowiednio $900 \mathrm{~kg} / \mathrm{m}^{3}$ - głowa, $1500 \mathrm{~kg} / \mathrm{m}^{3}$ - szyja, 1150 $\mathrm{kg} / \mathrm{m}^{3}$ - korpus;

- gęstość skrzydeł dobrano tak, aby całkowita szerokość modelu ptaka nie przekraczała szerokości szyby, gdyż wymagałoby to znacznych modyfikacji istniejącego modelu, ponadto, gęstość skrzydeł była determinowana całkowitą masą modelu ptaka i wynosiła ostatecznie $590 \mathrm{~kg} / \mathrm{m}^{3}$. 
Generując model ptaka przyjęto następujące uproszczenia:

- pominięto dziób, nogi i ogon ptaka;

- założono walcowy ze sferycznymi końcami kształt korpusu i głowy;

- założono walcowy kształt szyi;

- założono prostopadłościenny z zaokrąglonymi krawędziami kształt skrzydeł.

W modelu ptaka zastosowano ,zerowy” model materiałowy (*MAT_NULL), w którym zadeklarowano równanie stanu Grüneisena (*EOS_GRUNEISEN). Równanie to definiuje ciśnienie dla materiału ściskanego w postaci [14]:

$$
p=\rho_{0} C^{2} \mu\left\{\frac{\left[1+\left(1-\frac{\gamma_{0}}{2}\right) \mu-\frac{a}{2} \mu^{2}\right]}{\left[1-\left(S_{1}-1\right) \mu-S_{2} \frac{\mu^{2}}{\mu+1}-S_{3} \frac{\mu^{3}}{(\mu+1)^{2}}\right]^{2}}\right\}+\left(\gamma_{0}+a \mu\right) E,
$$

natomiast dla rozciąganego, jako:

gdzie:

$$
p=\rho_{0} C^{2} \mu+\left(\gamma_{0}+a \mu\right) E
$$

$C$ - prędkość dźwięku,

$\rho$ - gęstość aktualna,

$\gamma_{0}$ - parametr Mie-Grüneisena,

$S_{1}$ - współczynnik liniowy,

$\rho_{0}-$ gęstość początkowa,

$S_{3}$ - współczynnik sześcienny, $\quad E-$ energia wewnętrzna na jednostkę masy.

$\mu$ - parametr objętościowy, wyrażany jako $\mu=\left(\rho / \rho_{0}\right)-1$,

$a$ - współczynnik korekcji objętości pierwszego rzędu dla parametru $\gamma_{0}$

Tabela 2. Dane materialowe wykorzystane w modelu ptaka

\begin{tabular}{|c|c|c|c|}
\hline \multicolumn{2}{|c|}{$*$ MAT_NULL } & \multicolumn{2}{|c|}{ *EOS_GRUNEISEN } \\
\hline $\begin{array}{c}\text { ciśnienie odcięcia } \\
\text { (cut-off pressure) }\end{array}$ & $\begin{array}{c}\text { współczynnik lepkości } \\
\text { (viscosity coefficient) }\end{array}$ & $\begin{array}{c}\text { prędkość dźwięku } \\
\text { (bulk speed of } \\
\text { sound) }\end{array}$ & $\begin{array}{c}\text { współczynnik } \\
\text { liniowy } \\
\text { (linear coefficient) }\end{array}$ \\
\hline $\mathrm{PC}[\mathrm{Pa}]$ & $\mathrm{MU}[\mathrm{Pa} \cdot \mathrm{s}]$ & $\mathrm{C}[\mathrm{m} / \mathrm{s}]$ & $\mathrm{S} 1[-]$ \\
\hline$-10^{6}$ & 0,001 & 1647 & 2,48 \\
\hline
\end{tabular}

Uwzględniając powyższe dane oraz zastosowane uproszczenia uzyskano model ptaka o masie 3,604 kg złożony z 29972 cząstek SPH (rys. 1a). Wyniki symulacji porównano z wynikami dla modelu zastępczego ptaka o kształcie walcowym, ze sferycznymi końcami (rys. 1b), również o masie 3,6 kg i ilości cząstek SPH równej modelowi wielomateriałowemu. 
Numerical analysis of collision of the multimaterial bird model with helicopter... Analiza numeryczna zderzenia wielomateriałowego modelu ptaka...

(a)

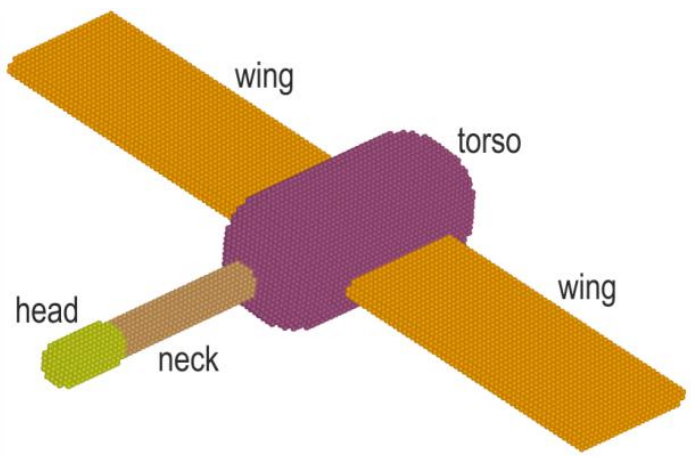

(b)

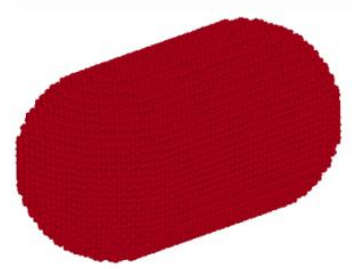

Rys. 1. Wielomaterialowy model ptaka wykorzystany $w$ analizach MES (a) oraz model o kształcie walcowym ze sferycznymi końcami (b)

\section{Wpływ kształtu modelu ptaka na wyniki badań}

Pierwsze analizy przeprowadzono dla prędkości przelotowej śmigłowca $285 \mathrm{~km} / \mathrm{h}$. Wyniki w postaci przebiegów czasowych ciśnienia i ugięcia szyby przedstawiono na rys. 2, odnosząc je do analogicznych przebiegów uzyskanych dla modelu ptaka o kształcie walcowym ze sferycznymi zakończeniami. Analizując uzyskane wyniki można wysnuć wniosek, że przyjęty kształt ptaka wpływa znacząco na zachowanie się szyby. Przebiegi ciśnienia dla modelu wielomateriałowego różnią się od tych uzyskanych dla modelu jednomateriałowego. Występują dwa piki wartości pierwszy odpowiadający uderzeniu głowy, a tak naprawdę szyi o bardzo wysokiej gęstości, drugi natomiast związany jest $\mathrm{z}$ uderzeniem korpusu. Ugięcia szyby osiągają zbliżone wartości ekstremalne, nie mniej jednak można zauważyć wolniejsze narastanie ugięcia $\mathrm{z}$ wiązane $\mathrm{z}$ kontaktem najpierw głowy, potem szyi, a dopiero na końcu - korpusu ptaka.
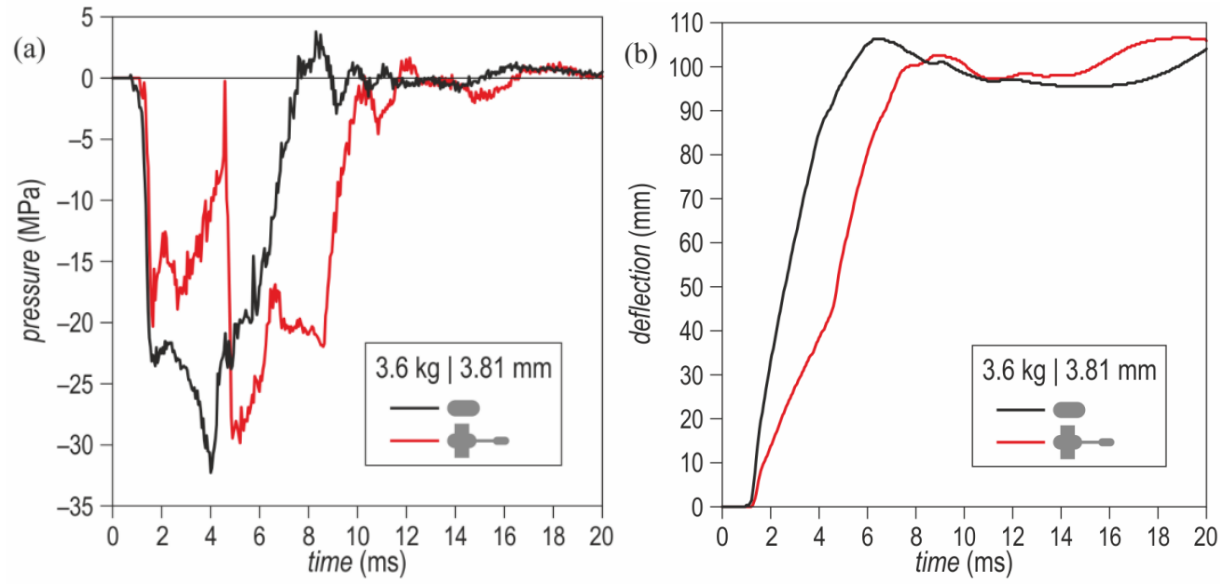

Rys. 2. Przebiegi czasowe ciśnienia (a) oraz ugięcia szyby (b) przy prędkości uderzenia $285 \mathrm{~km} / \mathrm{h}$. 
Janusz Ćwiklak

Masa ptaka wynosi 3,6 kg, natomiast grubość szyby jest równa 3,81 mm. Deformacje w wybranych chwilach czasowych porównano na rys. 3 .

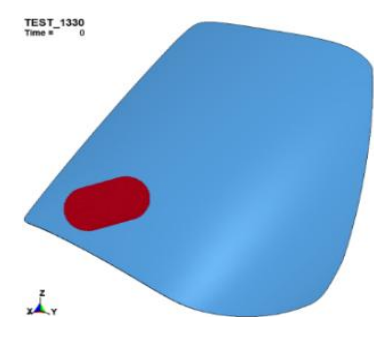

(a)
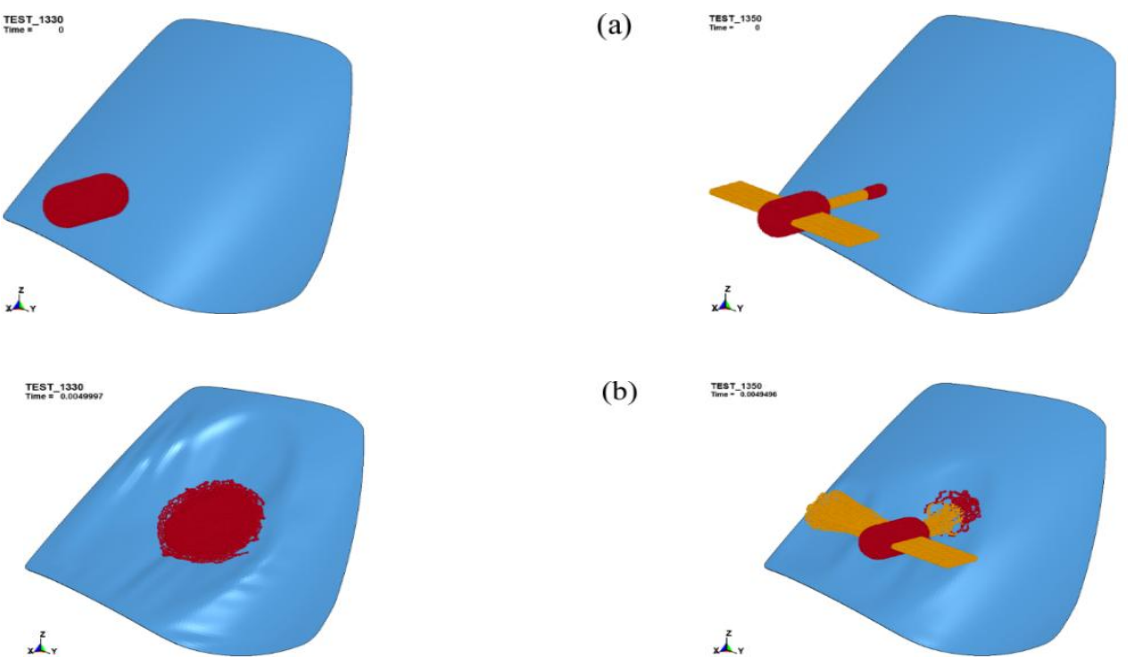

(b)
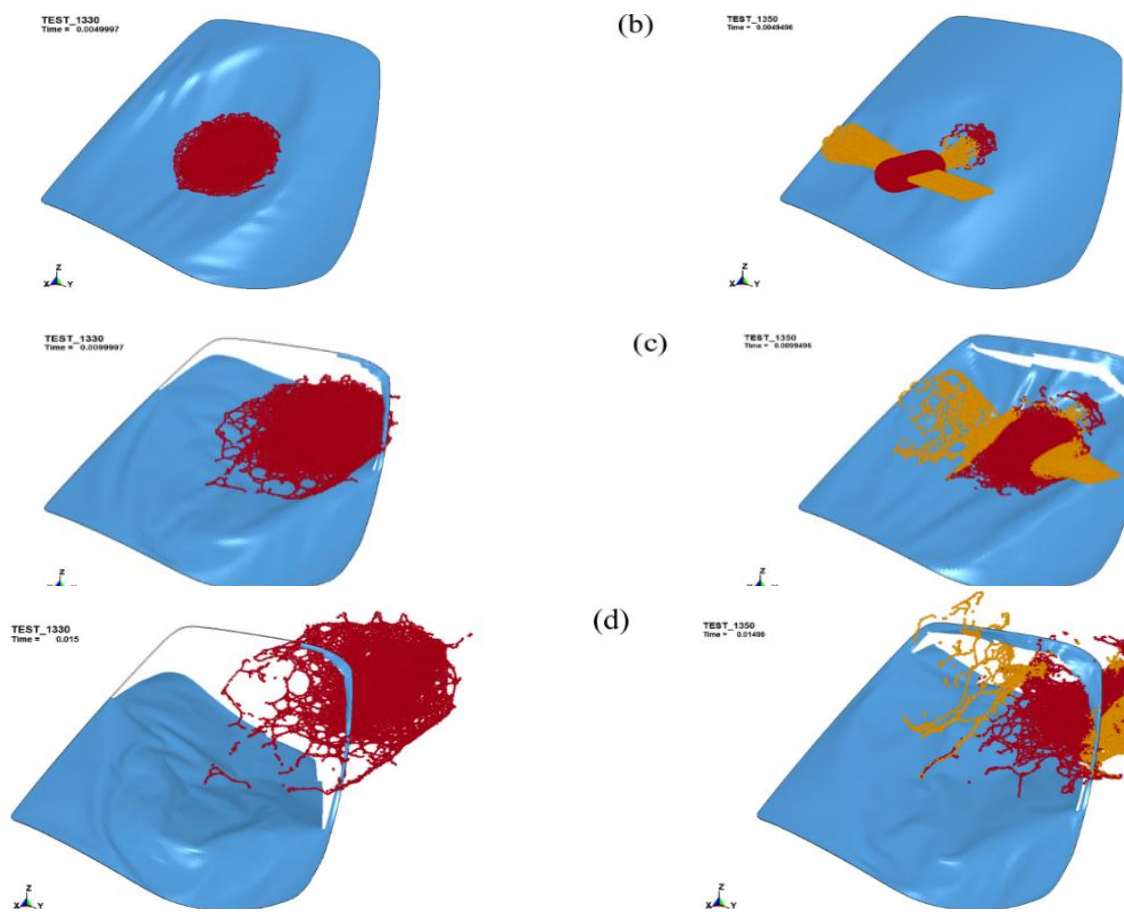

(c)

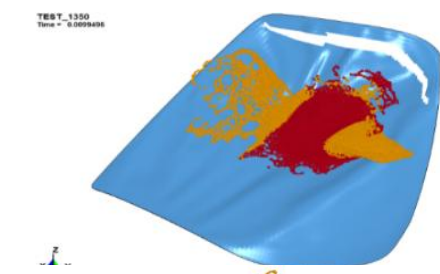

(d)
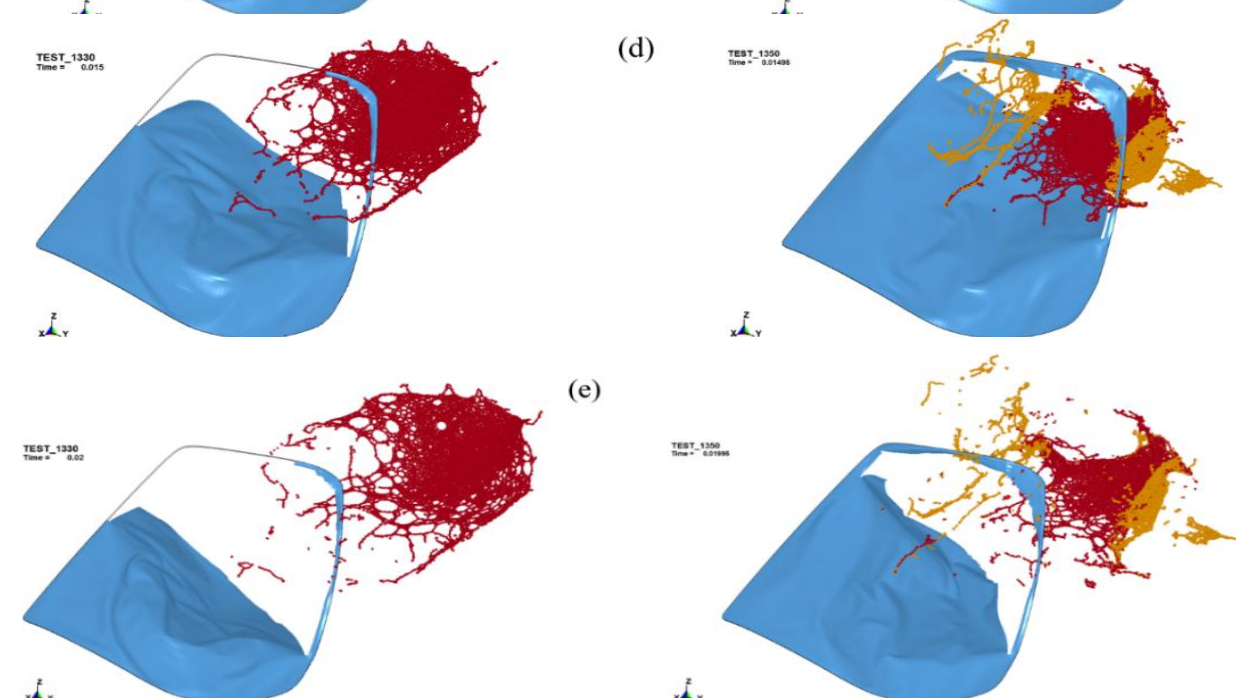

(e)

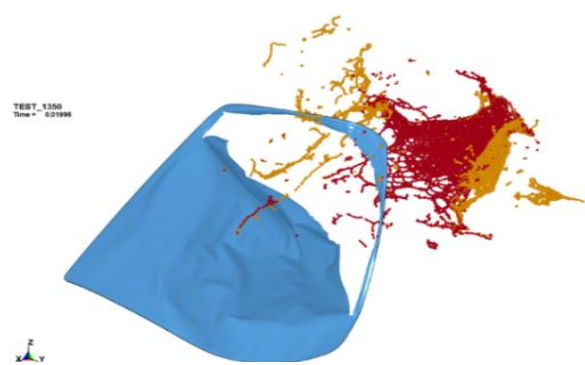

Rys. 3. Deformacje szyby wywotane uderzeniem ptaka o masie 3, $6 \mathrm{~kg}$ przy prędkości $285 \mathrm{~km} / \mathrm{h}$ (W kolumnie lewej-model ptaka o kształcie walcowym ze sferycznymi zakończeniami, w kolumnie prawej-wielomateriałowy model ptaka) 
Numerical analysis of collision of the multimaterial bird model with helicopter... Analiza numeryczna zderzenia wielomateriałowego modelu ptaka...

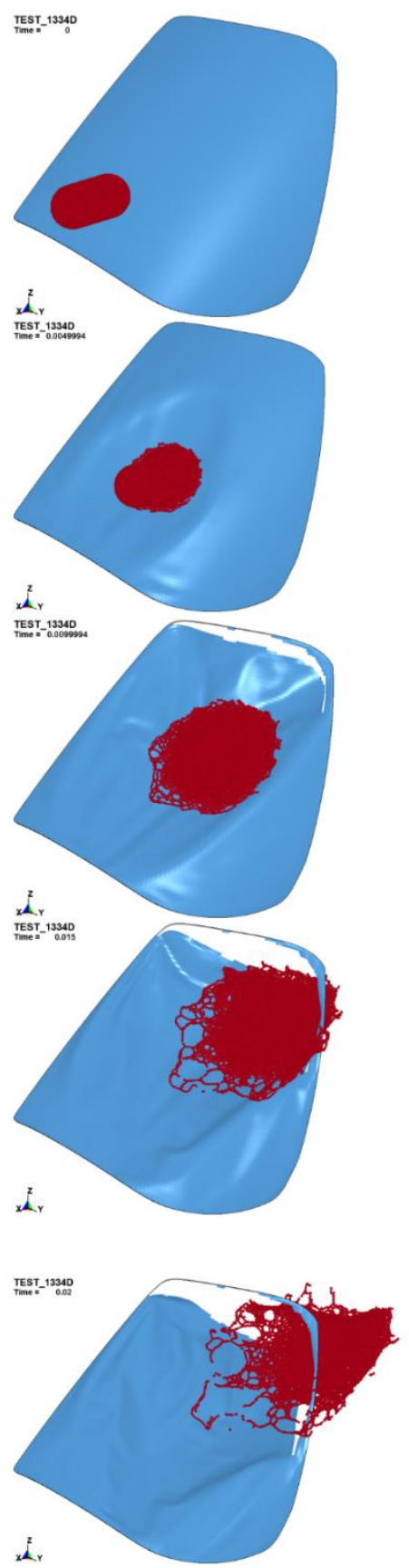

(a)

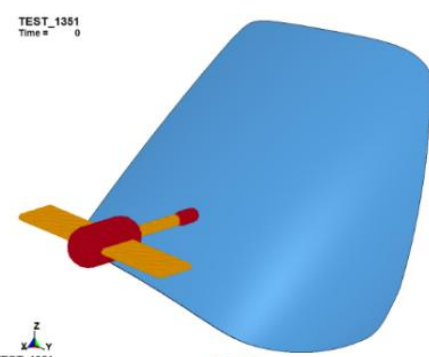

(b)

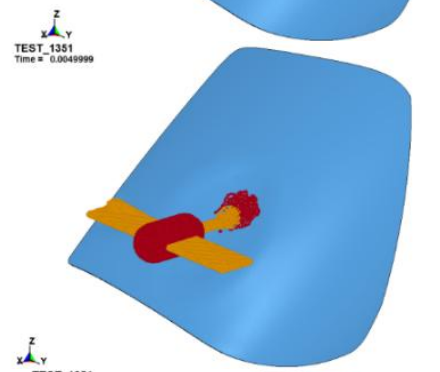

(c)<smiles>[C+]=[Si]C1CC[Si]1</smiles>

(d)

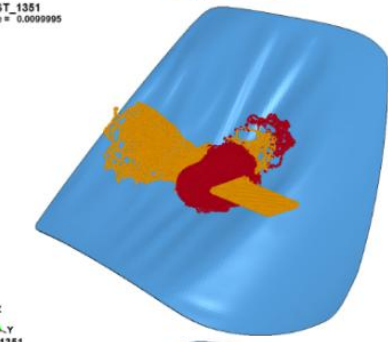

(e)

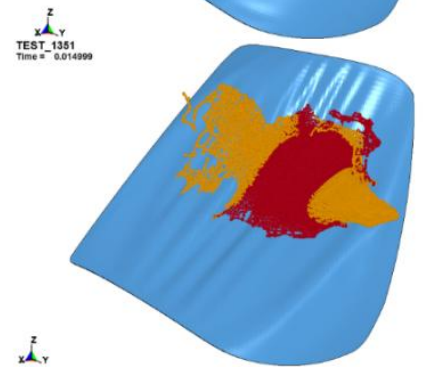

Rys. 4. Deformacje szyby wywotane uderzeniem ptaka o masie 3,6 kg przy prędkości lotu $200 \mathrm{~km} / \mathrm{h}$

W kolumnie lewej-model ptaka o ksztatcie walcowym ze sferycznymi zakończeniami, w kolumnie prawej-wielomateriałowy model ptaka 
Uzyskane wyniki dostarczają podstaw do wysnucia kolejnych wniosków, z których główny dotyczy sposobu niszczenia samej szyby, który jest tym razem bardziej zbliżony do rzeczywistego przypadku. Szyba nie niszczy się bezpośrednio w miejscu mocowania (w modelu MES jest to miejsce utwierdzenia), natomiast pękanie następuje w pewnej odległości od krawędzi szyby. Optycznie samo zniszczenie również jest znacznie mniejsze. Widać, zatem, że zbyt daleko posunięte uproszczenie, co do kształtu zastępczego ptaka (sfera, walec, czy walec ze sferycznymi zakończeniami), przy założeniu jednakowej gęstości materiału bardzo oddala badacza od spodziewanego, poprawnego wyniku. Zróżnicowanie gęstości masy modelu, nawet w modelu o tak uproszonym kształcie daje lepsze rezultaty.

Interesującą analizą porównawczą było sprawdzenie, czy zastosowanie wielomateriałowego modelu ptaka wpływa na prędkość, przy której następuje zniszczenie szyby. W klasycznym wariancie z 3,6 kg modelem ptaka o kształcie walcowym ze sferycznymi zakończeniami zniszczenie szyby nastąpiło przy prędkości $200 \mathrm{~km} / \mathrm{h}$ dla standardowej szyby $(3,81 \mathrm{~mm})$. Dla tej samej prędkości przeprowadzono symulację $\mathrm{z}$ wykorzystaniem modelu wielomateriałowego. Okazuje się, że zniszczenie szyby nie nastąpiło (rys. 4). W związku z tym, kształt zastępczego ptaka wpływa również na prędkość przy jakiej następuje pękanie szyby. Zbyt daleko posunięte uproszczenie kształtu zastępczego ptaka może zatem prowadzić do zaniżonych wartości tejże prędkości.
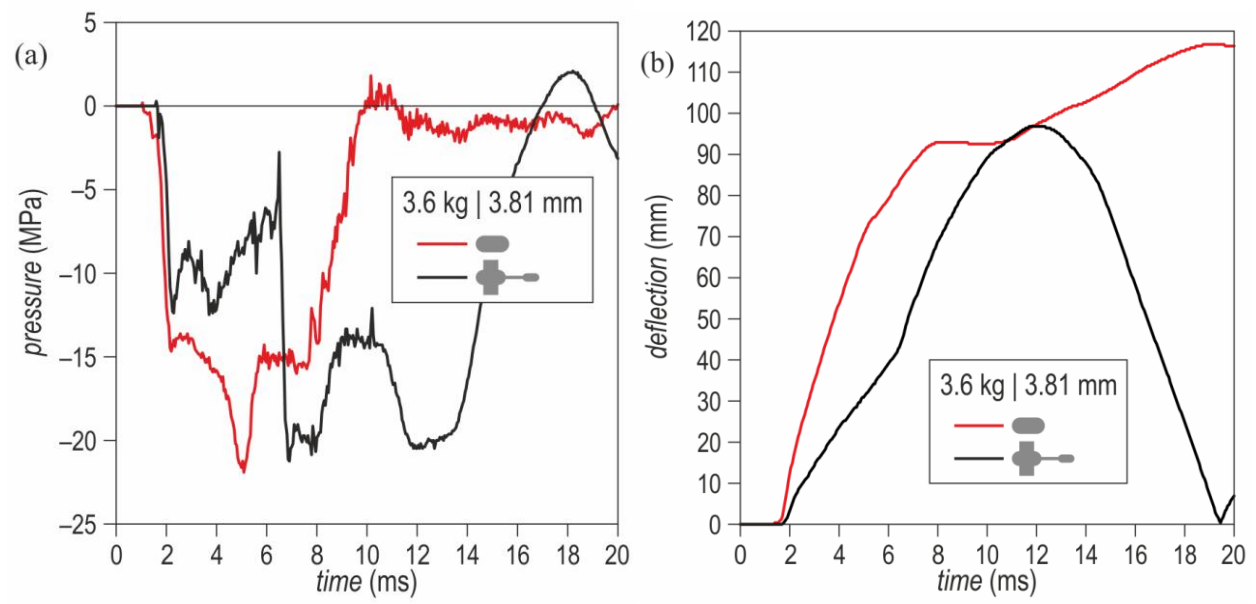

Rys. 5. Przebiegi czasowe ciśnienia (a) oraz ugięcia szyby (b) przy prędkości uderzenia równej $200 \mathrm{~km} / \mathrm{h}$. (masa ptaka - 3,6 kg, grubość szyby-3,81 mm)

Przebiegi czasowe wybranych wielkości przy prędkości $200 \mathrm{~km} / \mathrm{h}$ przedstawiono na rys. 5. Odnoszą się one do modelu ptaka o kształcie walcowym ze sferycznymi zakończeniami, w przypadku, którego przy tej prędkości nastąpiło już pękanie szyby oraz modelu wielomateriałowego, dla którego szyba pozostaje niezniszczona. 
Numerical analysis of collision of the multimaterial bird model with helicopter... Analiza numeryczna zderzenia wielomateriałowego modelu ptaka...

Tabela 3. Dopuszczalne prędkości zderzenia zastępczego ptaka o masie 3,6 kg z szyba, dla których nie następuje jej zniszczenie

\begin{tabular}{|l|r|r|}
\hline \multirow{2}{*}{ Model ptaka } & \multicolumn{2}{c|}{ Grubość szyby } \\
\cline { 2 - 3 } & $3,81 \mathrm{~mm}$ & $5,00 \mathrm{~mm}$ \\
\hline $\begin{array}{l}\text { jednomateriałowy o kształcie walcowym ze } \\
\text { sferycznymi zakończeniami }\end{array}$ & $195 \mathrm{~km} / \mathrm{h}$ & $210 \mathrm{~km} / \mathrm{h}$ \\
\hline wielomateriałowy o uproszczonym kształcie & $235 \mathrm{~km} / \mathrm{h}$ & $275 \mathrm{~km} / \mathrm{h}$ \\
\hline
\end{tabular}

W tabeli 3 zestawiono wartości prędkości zderzenia ptaka z szybą, dla których nie nastąpiło jej zniszczenie. Porównano model jedno- i wielomateriałowy w przypadku zderzenia czołowego ptaka z szybą rozpatrywanego śmigłowca. Widać, że w przypadku modelu o kształcie zbliżonym do rzeczywistego ptaka uzyskujemy prędkości znacznie wyższe, a zatem uproszczenie kształtu do walca nie daje miarodajnych wyników.

\section{Podsumowanie}

Ze względu na ograniczoną objętość artykułu przedstawiono tylko wybrane wyniki przeprowadzonych badań, odnoszące się do wpływu prędkości na proces niszczenia szyby w zależności od zastosowanego modelu ptaka.

Model ptaka, który jest wykorzystywany w analizach zderzenia z szybą statku powietrznego wymaga dużej dokładności wykonania, jeżeli chcemy, aby wyniki były zbliżone do rzeczywistych spotykanych w praktyce. Zbyt duże uproszczenia kształtu modelu ptaka mogą służyć jedynie wstępnej, zgrubnej ocenie zachowania się szyby $\mathrm{w}$ wyniku zderzenia $\mathrm{z}$ ptakiem. W zależności od stopnia złożoności modelu ptaka uzyskuje się zupełnie różnie postaci deformacji szyby oraz zróżnicowane przebiegi rejestrowanych wielkości.

Zastosowany model materiałowy wykorzystujący równanie stanu Grüneisena dość dobrze odzwierciedla zachowanie się modelu ptaka podczas dużych deformacji, które pojawiają się podczas zderzenia z szybą. Niemniej jednak zaleca się stosowanie modeli wielomateriałowych o zróżnicowanej gęstości masy poszczególnych komponentów.

Reasumując, przeprowadzone analizy numeryczne dają pogląd na zagadnienie zderzenia ptaka $\mathrm{z}$ szybą śmigłowca. Uzyskane wyniki są zbliżone do tych przedstawianych $\mathrm{w}$ pracach zawierających przedmiotową problematykę $[3,5]$. Zaproponowany zastępczy wielomateriałowy model ptaka o uproszczonym kształcie wydaje się być wystarczającym w tego typu analizach. Stanowi kompromis pomiędzy modelami o kształtach podstawowych (kula, walec), a modelami wiernie odzwierciedlającymi ptaka, trudnymi do generowania oraz weryfikacji. 


\section{Literatura}

[1] Marulo F., Guida M., Design criteria for birdstrike damage on windshield, Advances in Aircraft and Spacecraft Science, Vol. 1, No. 2, 2014, pp. 233-251.

[2] Bird strike simulation on a wing slat using Abaqus/Explicit, Abaqus Technology Brief, TB-10-BIRD-1, 2010.

[3] McCallum S. C., Constantinou C., The influence of bird-shape in bird-strike analysis, 5th European LS-DYNA Users Conference, Paper No. 2c-77, Birmingham, United Kingdom 2005.

[4] Heimbs S., Computational methods for bird strike simulations: A review, Computers and Structures, Vol. 89, 2011, pp. 2093-2112.

[5] Wang F. S., Yue Z. F., Yan W.Z., Factors study influencing on numerical simulation of aircraft windshield against bird strike, Shock and Vibration, Vol. 18, 2011, pp. 407-424.

[6] Boguszewicz P., Sala S., Bird Strike, czyli zderzenie z ptakiem, Prace Instytutu Lotnictwa, Vol. 213, s. 101-111, 2011.

[7] Jun L., Yulong L., Xiaosheng G., Xiancheng Y., A numerical model for bird strike on sidewall structure of an aircraft nose, Chinese Journal of Aeronautics, Vol. 27, No. 3, 2014, pp. 542-549.

[8] Safety Recommendation, A-09-72 through -81, National Transportation Safety Board, Washington, D.C. United States, 2009.

[9] Lavoie M.-A., Gakwaya A., Nejad Ensan M., Zimcik D. G., Review of existing numerical methods and validation procedure available for bird strike modelling, ICCES, Vol. 2, No. 4, 2007, pp. 111-118.

[10] Nagaraj V, Velmurugan T., Numerical bird strike impact simulation of aircraft composite structure, IOSR Journal of Mechanical and Civil Engineering.

[11] http://www.dynaexamples.com/sph.

[12] https://grabcad.com/library/augusta-a-109-1.

[13] N109TK, EW/C2011/07/10, AAIB Bulletin, 3/2012.

[14] LS-DYNA ${ }^{\circledR}$ Keyword User's Manual, Vol. I, Livermore Software Technology Corporation, USA 2007.

[15] Allcock A. W. R., Collin D. M., The development of a dummy bird for use in bird strike research, Aeronautical Research Council, C.P. No. 1071, Ministry of Technology, United Kingdom 1969.

[16] http://www.agustawestland.com/product/helicopters/aw109-power-2.

[17] http://www.dynasupport.com/tutorial/ls-dyna-users-guide/time-integration.

[18] Konderla P., Metoda Elementów Skończonych, teoria i zastosowania, kurs na studiach doktoranckich Politechniki Wrocławskiej, Wrocław 2007. 
Numerical analysis of collision of the multimaterial bird model with helicopter... Analiza numeryczna zderzenia wielomateriałowego modelu ptaka...

[19] LS-DYNA ${ }^{\circledR}$ Theory Manual, Livermore Software Technology Corporation, USA 2006.

[20] Wróblewski P., Algorytmy symulacji płynów rzeczywistych bazujące na modelach DPD oraz SPH dla komputerów z pamięcią współdzieloną oraz rozproszoną, rozprawa doktorska, Akademia Górniczo-Hutnicza w Krakowie, Kraków 2009.

[21] Wróblewski P., Boryczko K., Implementacja równoległa, zastosowania i wyniki metody SPH w przypadku symulacji płynów nieściśliwych, Automatyka, t. 12, z. 2, 2008, s. 389-406.

[22] https://pl.wikipedia.org/wiki/SPH.

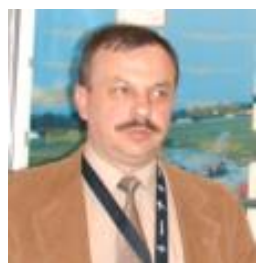

Dr pil. Janusz Ćwiklak zwiazany jest z lotnictwem od 1976 roku. Jest absolwentem kierunku „pilot samolotu odrzutowego" Wyższej Oficerskiej Szkoty Lotniczej. Ukończyt studia magisterskie na Politechnice Lubelskiej. W 2002 roku na Uniwersytecie Warmińsko-Mazurskim obronit rozprawe doktorska uzyskują stopień doktora nauk technicznych w zakresie geodezji i kartografii. Zajmuje się działalnościa naukowa, zwiąana $z$ zastosowaniem systemów satelitarnych $w$ lotnictwie. Prowadzi badania poświęcone zagadnieniom bezpieczeństwa lotów, ze szczególnym uwzględnieniem problematyki zapobiegania kolizjom statków powietrznych z ptakami. Uczestnik wielu konferencji międzynarodowych $i$ krajowych. Od 2008 roku pracuje $w$ WSOSP jako cywilny nauczyciel akademicki, petniac funkcje prodziekana Wydziału Lotnictwa. 